\title{
Diyabetli Bireylerle Etkili İletişim için Nasıl Bir Dil Kullanılmalı?
}

\author{
What Kind of Language Should be Used to Communicate Effectively with People with Diabetes?
}

\section{Canan Uysal ${ }^{1}$, Emel Özer ${ }^{2}$}

Geliş tarihi/Received: 08.10.2019 • Kabul tarihi/Accepted: 27.11.2019

\section{ÖZET}

Diyabetli bireyler diyabetli olmayanlara klyasla duygusal stresi daha fazla deneyimler. Bu stresi oluşturan kaynaklardan birisi de diyabetli ve diyabetli yakınlarına yönelik olarak sözlü veya yazılı iletişimde kullanılan dildir. İletişimin temel aracı olan dilin sözlü ve/veya yazılı iletişimde iyi kullanılması güven oluşturabilir, önerilen tedaviyi uygulama isteğini arttırabilir, öz yönetimi destekleyebilir ve yaşam kalitesini artırabilir. İyi dil kullanımı kaygının azalmasını, güven oluşmasını, kendi kendine diyabet yönetiminin geliştirilmesine yardımcı olur. Damgalayıcı, incitici sözcükler, tanımlamalar klinik sonuçlar ve yaşam kalitesi üzerinde olumsuz etkiye neden olabilir. Bu derleme, diyabet tedavisinde kullanılan sözcüklerin ve yüklediği anlamların tedavi sürecinde diyabetli bireyler üzerindeki etkileri konusunda farkındalık yaratmak, diyabetin konuşulan veya yazılı kelimelerle kullanılan dili için sunulan önerileri paylaşmak amacıyla hazırlanmıştır.

Anahtar kelimeler: Diyabet, dil, iletişim, uyum, kontrol

\begin{abstract}
People with diabetes experience more emotional stress than those without diabetes. One of the sources of this stress is the language used in verbal or written communication for people with diabetes and their relatives. Good use of language, which is the main tool of communication, in oral and / or written communication can build trust, increase the desire to apply the recommended treatment, support self-management and improve the quality of life. Good language use helps to reduce anxiety, build trust and improve diabetes management. Stigmatizing, offensive words and descriptions may have a negative impact on clinical outcomes and quality of life. This review has been prepared to raise awareness of the effects of the words and the meanings used in the diabetes treatment on people with diabetes during the treatment process, and to share suggestions for the language of diabetes spoken or written.
\end{abstract}

Keywords: Diabetes, language, communication, adherence, control

\section{GíRIŞ}

Diyabet, sürekli tıbbi bakım gerektiren karmaşı, kronik bir hastalıktır. Akut komplikasyonların önlenmesi ve uzun vadeli komplikasyon riskinin azaltılması için öz yönetim eğitimi ve desteği kritik öneme sahiptir (1). Hasta merkezli tedavi yaklaşımı, hasta merkezli iletişimi gerektirdiğinden son yıllarda hasta deneyimi, iletişim ve diyabetliler için hayatın nasıl daha iyi hale getirilebileceği sıkça
1. İletişim/Correspondence: Diyabet Diyetisyenliği Derneği, İstanbul, Türkiye E-posta: dytcananuysal@gmail.com • 은tps://orcid.org/0000-0001-7064-511X
2. Diyabet Diyetisyenliği Derneği, İstanbul, Türkiye (ㄱ) https://orcid.org/0000-0002-4394-8761 
tartışılmaktadır. Diyabet yönetiminde diyabetli bireylerle daha etkili bir iletişimin nasıl kurulabileceği ile ilişkili bilgiler olmasına karşın, diyabetli bireyle sözel ve/veya yazılı iletişimde kullanılan dilin nasıl olması gerektiği konusunda çok az şey bilindiği bildirilmektedir (2,3). Bilgi ve anlayışı paylaşmanın başlıca aracı olarak kabul edilen dil, Türk Dil Kurumu (TDK) sözlüğünde;

1. İnsanların düşündüklerini ve duyduklarını bildirmek için kelimelerle veya işaretlerle yaptıkları anlaşma, lisan, zeban

2. Bir çağa, bir gruba, bir yazara özgü söz dağarcığı ve söz dizimi,

3. Belli mesleklere özgü dil: Örn. Hukuk dili

4. Düşünce ve duyguları bildirmeye yarayan herhangi bir anlatım aracı: Müzik dili, yazı dili olarak tanımlanmaktadır (4).

Dil; tutum değişikliğinin, sosyal algının, kişisel kimliğin, gruplar arası eğilimin, klişeleştirmelerin merkezinde yer almaktadır. Belirli kelimeler veya ifadelerin kullanımı kasten veya istemeden cinsiyet, din, ırk, sağlık gibi kişisel özelliklerle ilgili önyargıları ifade edebilmektedir. Sözcüklerin 'güçlendirici' veya 'yok edici' gücü vardır ve bu güç diyabetle yaşayan bireylerin stresli deneyimine olumsuz ve aşağılayıcı ifadeler ile katkıda bulunan dil için de geçerlidir. Bireylerin duyduklarına ya da okuduklarına yükledikleri anlam kendilerine ve var olan hastalığa yönelik algılarını etkileyebilmektedir $(2,3)$. Llyond et al. (5), dikkatlice seçilmiş dilin olumlu bir etkiye sahip olmasına rağmen, dilin bireylerin diyabet bakımı deneyimleri üzerinde potansiyel olumsuz bir etkisi olduğuna da dikkat çekmişlerdir. Cesaret verici ve işbirliğine dayalı mesajlar içeren dil, tedaviye yönelik isteklendirmeyi ve davranışı olumlu etkileyerek sağlıkla ilgili sonuçları geliştirebilmektedir. Diyabetli bireyle olan iletişimde nasıl konuşulduğu, yazı dilinin ve beden dilinin nasıl kullanıldığı diyabet yönetiminin ve psikososyal iyiliğin gelişmesinde önemli rol oynamaktadır (2,3,5-9).
$\mathrm{Bu}$ derleme, diyabet tedavisinde kullanılan sözcüklerin ve yüklediği anlamların tedavi sürecinde diyabetli bireyler üzerindeki etkileri konusunda farkındalık yaratmak, diyabetin konuşulan veya yazılı kelimelerle kullanılan dili için sunulan önerileri paylaşmak amacıyla hazırlanmıştır.

\section{Hasta Merkezli Bakım}

Hasta merkezli bakım yaklaşımının elli yıldan fazla bir süredir tıbbi kaynaklarda yer aldığı (10) ve günümüzde diyabet tedavisinde mümkün olan en iyi sağlık sonuçlarının elde edilmesi için önerilen tedavi yaklaşımı olduğu bildirilmektedir (11). Amerikan Tıp Enstitüsü’nün (Institute of Medicine[IOM]), hasta merkezli bakımı 'hastaların isteklerine, gereksinimlerine ve tercihlerine saygı gösteren, kendi bakım planlarına karar vermek ve bakım kalitelerini geliştirmek için ihtiyaç duydukları eğitim ve desteğe sahip olmalarını sağlayan, uygulayıcılar ile hastalar ve hasta yakınları arasındaki bir ortaklık' olarak tanımladığı bildirilmiştir (12). Bu tanımla hasta sağlığı üzerinde sadece hastaların değil hasta yakınlarının da rolü olduğu vurgulanmıştır. Hasta merkezli bakım kapsamında, ilgili sağlık hizmeti sağlayıcıları ve hasta arasında dinamik ve işbirliğine dayalı bir ilişki yer alır. Hasta merkezli bakım ile öz yönetim, yaşam kalitesi ve tedavi memnuniyeti arasında anlamlı bir ilişki olduğu bildirilmiştir $(10,13)$.

\section{Hasta Merkezli İletişim}

Hasta merkezli bakımın temelinde hasta merkezli iletişim yer alır. İletişim TDK sözlügünde 'duygu, düşünce veya bilgilerin akla gelebilecek her türlü yolla başkalarına aktarılması, bildirişim, haberleşme, komünikasyon’ olarak tanımlanmaktadır (4).

Diabetes Care'de yayınlanan 'Diyabette Tıbbi Bakım Standartları-2019' kapsamında, yazarlar sağlık sonuçlarını ve sağlıkla ilgili yaşam kalitesini en iyi duruma getirmek amaciyla aktif dinlemeyi sağlayan, hasta tercihlerini ve inançlarını ortaya çıkaran, okuryazarlığı, temel aritmetik kavramlarını kavrama yeteneğini ve bakım için potansiyel 
engelleri değerlendiren hasta merkezli iletişim çağrısı yapmışlardır (14). Hasta merkezli bakım veren sağlık uzmanlarının hasta merkezli iletişim sağlaması, hasta merkezli iletişimi sağlayabilmesi için de gelişmiş iletişim becerilerine sahip olması gerekmektedir.

Paiva et al. (15), yapılan çalışmalarda hasta merkezli iletişimin gelişmiş hastalık bilgisi ve öz bakım yeterliliği, artmış yaşam kalitesi ve metabolik parametrelerde iyileşme ile ilişkilendirildiğini bildirmişlerdir. Naughton (12), hasta merkezli iletişimin içerdiği temel kavramları tanımlamıştır. $\mathrm{Bu}$ kavramlar:

1. Hastanın bakış açısını ortaya çıkarmak ve anlamak (örneğin; endişeler, fikirler, beklentiler, ihtiyaçlar ve duygular),

2. Hastayı psikolojik, sosyal ve kültürel bağlamlarında anlamak,

3. Hasta sorunları ve hasta değerleriyle uyumlu tedaviler için ortak bir anlayışa varmaktır.

Amerikan Diyabet Eğitimcileri Derneği (American Association of Diabetes Educators [AADE] ve Amerikan Diyabet Derneği (American Diabetes Association [ADA]), diyabetlilerle ve yakınlarıyla iletişim sağlamak için benimsenmesi gereken dört temel ilke olduğunu bildirmişlerdir (Tablo 1) $(2,3)$.

Amerikan Tip Derneği'nin (American Medical Association [AMA]) 'AMA Stil El Kitabı'nda yazarlara yapılan çağrıda 'İnsanları engelleri veya hastalıkları (örneğin, kör, şizofreni, epileptikler) ile etiketlemekten (ve böylece eşitlemekten) kaçının. Bunun yerine, önce bireyi koyun. İnsanları kurban olarak veya çaresiz (sakat, acı çeken, sakat kalmış) gösteren duygusal terimlerle tanımlamaktan kaçının' ifadeleri yer almaktadır (16). Bu bilgiler ışığında ülkemizde sözel ve yazılı iletişimde sıklıkla kullanılan 'diyabetik' tanımlaması yerine 'diyabetli birey' tanımlamasının kullanılması gerektiği açıkça anlaşılmaktadır.

ADA ve AADE, AMA'nın yukarıda belirtilen önerileri dikkate alarak diyabette etkili iletişimi daha iyi tanımlamak, birey merkezli, güçlü iletişim sağlamak amacıyla belirlenmiş beş dil özelliğinin kullanılmasını önermektedir (Tablo 2) $(2,3)$.

\section{Sağlıkta İletişim ve İletişim Engelleri}

Halk sağlığında sağlıkta iletişimin önemi vurgulanmıştır (17-19). Amerika Birleşik Devletleri'nin (ABD) Sağlıklı İnsanlar 2010 (Healthy People 2010) hedeflerinde, ilk kez sağlıkta iletişimin önemini gösteren bir bölüme yer verilmiştir (18). Amerikan Sağlık ve İnsan Hizmetleri Bakanlığı'nın sağlık iletişimi tanımını ve kapsamını 'Önemli sağlık sorunları hakkında bireysel, kurumsal ve kamu izleyicilerini bilgilendirme, etkileme ve motive etme sanatı ve tekniğidir. Sağlık iletişiminin kapsamı, hastalıkların önlenmesi, sağlığın teşviki, sağlık hizmetleri politikası ve sağlık hizmetinin yanı sıra

Tablo 1. Diyabetle yaşayanlarla iletişim için rehber ilkeler $(2,3)$

1. Diyabet, birçok faktör ve değişken içeren kompleks ve zorlu bir hastalıktır.

2. Diyabet tanısına bağlı olan damgalama; stres, utanç ve yargılanma hissine katkıda bulunabilir.

3. Sağlık ekibinin her bir üyesi, diyabetli bireyler saygılı, işbirlikçi ve birey odaklı bir yaklaşımla daha etkili bir şekilde hizmet edebilir.

4. Birey odaklı, bireye öncelik ve güç veren, yetkilendirici bir dil diyabetli bireylerle olan iletişimi, bireyin istekliliğini, sağlığını ve iyilik halini geliştirebilir.

Tablo 2. Bireye merkezli, güçlü iletişim için önerilen dil özellikleri $(2,3)$

1. Nötr, yargısız, duruma, eylemlere ve fizyoloji / biyolojiye dayalı dil

2. Damgalamayan dil

3. Güç ve umut veren, saygllı dil

4. Hastalar ve sağlık bakımı verenler arasında işbirliğini teşvik eden dil

5. Bireye odaklı dil 
toplum içindeki bireylerin yaşam kalitesini ve sağlığını iyileştirmeyi içerir' şeklinde ifade ettiği bildirilmektedir (19).

Sağlık uzmanları, hastaların tedavileri hakkında bilgilendirilmelerini sağlamak için daha katılımcı bir rol oynamaları gerektiğini kabul etmelerine rağmen, iletişimle ilişkili çeşitli engeller mevcuttur. $\mathrm{Bu}$ engellerden birinin zaman, bir diğerinin ise hastalara kanıta dayalı tedavi planlarının sunulması diğer bir ifade ile hastayı değil hastalığı merkez alan tedavi yaklaşımı olduğu bildirilmektedir (12). Sağlık bakımı sağlayanların genellikle hastayı dinlemek, açıklamalarda ve paylaşımda bulunmak için yeterli zaman olmadığından yakındığı, hastaların da endişelerini tamamen ifade edemeden görüşmenin bitirilmesinden yakındıkları belirtilmektedir (12). Tedavi rehberleri, sağlık uzmanlarına diyabetli bireylere verecekleri tedavi seçenekleri hakkında tavsiyede bulunmalarına yardımcı olmaktan çok hastalığa odaklı hedefler ve metrik öneriler üzerine yapılandırılmış tedavi prensiplerine yer vermektedir (6). Diyabet görülme sıklığının oldukça yüksek olduğu Güney Asya'da yaşayan tip 2 diyabetli bireylerin tedavisindeki engellerin ele alındığı sistematik bir derlemede, sağlık hizmeti verenlerin kullandıkları dilin ve iletişim uyuşmazlığının diyabet eğitiminin alınmasında ve anlaşılmasında önemli bir engel olduğu belirlenmiştir (20). 'Diyabet Tutumları, Dilekler ve İhtiyaçlar (Diabetes Attitudes, Wishes and Needs Second Study [DAWN2 ${ }^{\mathrm{TM}}$ ) (çalışmasından elde edilen sonuçlar, hasta merkezli bakımın çoğu zaman kullanılamadığını, diyabetli bireylerin psikolojik, sosyal ve beslenme tedavisi ile ilişkili gereksinimlerinin karşılanmadığını göstermektedir (21). İngiltere'de yapılan bir çalışmada, sağlık sistemine dair hasta yakınmaları sınıflandırılmış ve hastaların en fazla tedavi sağlayıcıları ve diyabetli bireyler arasındaki iletişim başarısızlıklarından yakındıkları saptanmıştır (22).

'Sağlıklı İnsanlar 2010' hedeflerinin değerlendirilmesinde sağlık hizmeti sağlayıcılarının iletişim becerileri kapsamında hasta memnuniyeti, dört alt hedef aracılığıyla izlenmiştir. Bu başlıklar; hastaların sağlık hizmeti sağlayıcılarının onları dinleme becerilerindeki algıları, anlaşılır açıklamalar sunmuş olmaları, hastalara gösterdikleri saygı ve onlarla yeterince zaman geçirmeli olarak belirlenmiştir. Bu dört alt hedefin her biri için, sağlık sağlayıcılarını olumlu değerlendirenlerin oranının, 2000 ve 2001 ylllarında belirlenmiş hedeften \%1-2 oranında uzaklaştığı saptanmıştır (18).

İletişim becerileri, sağlık okuryazarlığının da önemli bir bileşenidir çünkü genel okuryazarlık ve sağlık okuryazarlığı, ilgili bilgiyi edinme, işleme, anlama, yorumlama yeteneğinin yanı sıra kullanma yeteneğini de gerektirir ve tüm bu faktörler dilden etkilenir $(6,12)$.

\section{Sağlıkta İletişim ve Dil}

Hasta merkezli bakımın bel kemiği olan iletişim, temel bir klinik yetkinlik olarak kabul edilmektedir (6). Diyabetli bireylere bakım ve hizmet sunan sağlık uzmanlarının; diyabet ve diyabetli bireyle ilişkili olası önyargılarının ve kullandıkları terminolojinin, kendileri ve diyabetli birey arasındaki iletişimi ve diyabetli bireyin aldığı bakım hizmetinin içeriğiyle olan ilişkisini etkileyebileceğini bilmeleri önemlidir (59). Şimdiye dek, birey odaklı dili kullanma konusunda evrensel bir mutabakat olmamasına karşın diyabette birey odaklı dilin, diyabetli bireyi pasif bir alıcı olmak yerine diyabeti kendi kendine yönetmesinde aktif bir role sahip kıldığı belirtilmektedir $(2,3)$.

Sağlık mesleklerinin dili her zaman insanların günlük yaşamda kullandığı dil ile aynı değildir. Sağlık okuryazarlığı, dil kodları/ lehçeleri ve dil yeterliliği iletişimi tehlikeye atabilir. Bu faktörlerin sağlık sonuçları ve sağlıkla ilgili maliyetlerin önemli belirleyici olduğu bildirilmektedir (6). Sözlü iletişim dışında sağlıkta bir diğer iletişim kaynağı bilginin yazı diliyle aktarıldığı basılı materyallerdir. Hasta eğitim materyalinin 5-8. sinıf ders kitaplarının okunabilme düzeyine uygun bir dille hazırlanması önerilmekle birlikte çoğu yazılı diyabet bilgisinin en az 9. sınıf düzeyinde olduğu bildirilmiştir. Okuma düzeyine uygunluğun tanımı, 6-8. sınıf ders kitaplarındaki 
kelime ve cümle uzunluğuna benzer kelime ve cümlelerin yer aldığı, okunabilir yazılı materyal anlamindadır (23).

Amerika'da Medicare ve Medicaid olarak bilinen sağlık sigortası sistemleri, insanların basılı materyallerdeki yazıları okumasını, anlamasını ve kullanmasını kolaylaştırmak amacı ile hazırladıkları 'Yazılı Materyali Net ve Etkili Hale Getirmek İçin Araç Kiti' ile yazarlara yardımcı olacak ayrıntılı ve kapsamlı bilgilendirmede bulunmuştur (24). Tedavi sağlayan sağlık uzmanlarının, diyabetli bireylerle tedaviye yönelik ilişkiler kurmak, bilgi koordine etmek ve bireyselleştirilmiş bakım planları ve bakım hedefleri üzerinde anlaşmaya varmak için son derece etkili iletişimciler olmaları gerekir (6-9).

\section{Diyabet Bakımı ve Eğitiminde Dilin Kullanımına Yönelik Öneriler}

Ylllar boyunca, diyabet ile ilişkili dilin önemli bir kısmı, yargı ve suçlamalarla yüklü olumsuz sonuçlara odaklanmış, bireysel ihtiyaçlar, inançlar ve seçimler yeteri kadar dikkate alınmamıştır $(2,3)$.

Diyabet Avustralya (Diabetes Australia), diyabet yönetiminde kullanılan dilin 'hatalı ve zararlı' olabileceğini belirlemiş ve "Diyabet için yeni bir dil" başlığında bir rapor yayınlamıştır (9). Bu yayında diyabet bakım ve eğitiminde kullanılan bazı dil seçeneklerinin olumsuz davranışsal sonuçları özetlenmiş, diyabete kullanılan dil ile ilişkili farkındalık oluşturmak ve daha dikkatli, pozitif bir dilin kullanılmasını sağlamak için öneriler sunulmuştur (9). Uluslararası Diyabet Federasyonu (International Diabetes Federation [IDF]) ise diyabet alanindaki sorumluluğuna vurgu yaparak 'Dil Felsefesi' başlığı yayını ile sağlık çalışanlarında farkındalık oluşturmaya çalışmıştır (25). Obezite Derneği'nin (The Obesity Society) de birey odaklı dili resmen benimsediği, 'obez/şişman' yerine “obezitesi/ şişmanlığı olan birey’ demenin daha kabul edilebilir olduğu bildirilmiştir (26).

İngiltere Ulusal Sağllk Hizmeti (National Health Service [NHS]) 2018 yılı haziran ayında 'Dil Sorunu,
Diyabette Dil' başlığı ile sağlık çalışanlarına yönelik bir rapor yayınlamıştır. Raporda, 'sağlık uzmanları olarak diyabetle yaşayanların hayatlarını yaşamıyoruz, onları kısa bir an için görüyoruz, dolayısıyla sözlerimizin diyabet bakımı üzerindeki etkisinin farkında olmamız gerektiğini hatırlamak zorundayız. Yaklaşımın yargılayıcı değil işbirlikçi ve kapsayıcı olması gerekir; kelimelerin (sözel veya yazılı), özellikle uzun vadeli bir durumun belirlenmesinde, bireyin anlayabileceğinden çok daha büyük bir etkisi olabilir.' ifadeleri yer almaktadır. Rapor kapsamında NHS, diyabet ve dil ile ilişkili olarak sağlık çalışanları dışında diyabetli bireylerin de görüşlerine yer vermiştir (8).

İngiltere Diyabet Birliği (Diabetes U.K.)'nin, diyabetli ve kilit paydaşları temsil eden bireylerden oluşan bir çalışma grubu, sağlık profesyonellerinin diyabetle yaşayanlarla etkileşimini geliştirmek, bu konuda rehberlik etmek amacıyla diyabet ve dil ile ilişkili olarak aşağıda verilen prensipleri geliştirmiştir $(5,7)$.

- Hem sözel hem de sözel olmayan dilin olumlu ya da olumsuz etkileri olabilecek muazzam bir güce sahip olduğunu unutmayın.

- Kullanıcinin niyeti ne olursa olsun bazı kelimelerin, ifadelerin ve açıklamaların potansiyel olarak sorunlu olduğunu kabul edin.

- Özellikle uzun vadeli sonuçlardan veya azarlama tehdidinden kaçınmaya çalışarak; yargı ve olumsuz çağrışımlardan arınmış, otoriter veya kontrol eden olmaktan çok işbirlikçi ve ilgi çekici olan, bireyi durumu olarak etiketlemeyen (örneğin diyabetik) ses tonu ve vücut dilini de kapsayan birey merkezli dili kullanın (örneğin diyabetli birey).

- Genel ifadelerin kullanımını ve hangi temel tavırları taşıyabileceklerini gözden geçirin.

- Diyabetinin gelişmesi veya sonuçları için bireye sorumluluk veya suçlama yönelten dilden kaçının.

- Genelleme, basmakalıp ya da önyargı ima eden 
dillerden ya da bireyi benzer bir geçmişe sahip olan veya benzer bir durumda olan başkalarının önceki deneyimleriyle ilişkilendiren dilden kaçının.

- Bireyin kendi koşullarına bakış açısını belirlemeye çalışmak yerine empatik bir dil tarzı kullanın ya da geliştirin.

- Bireyin diyabetiyle ilgili kendi sözcüklerini veya ifadelerini dinleyin ve arkasındaki anlamları keşfedin veya onaylayın.

- Dil kullanımı konusunda özenli olun ve kullanılan dilin olumsuz bir etki yaratıp yaratmadığını anlayın. Hem kendiniz hem de çevrenizdeki diğer kişiler için kullanılan olumsuz dil etkilerini nasıl sınırlayacağınızı düşünün

Dilin dikkatli kullanılmasının sadece sağlık uzmanlarının sorumluluğunda olmadığı, diyabetli bireyin günlük yaşamında iletişim içinde olduğu sağlık hizmeti sunucularının, aile bireylerinin, arkadaşların, meslektaşların ve özellikle medyanın da bu sorumluluğu aynı düzeyde sahiplenmesi gerektiği vurgulanmaktadır $(2,3,5,7,8)$.

ADA'nın yayın organı olan Diabetes Care ve AADE'nin yayın organı olan Diabetes Educator adlı dergilerde 2017 yllında 'Diyabet Bakım ve Eğitiminde Dilin Kullanımı' başlıklı bir makale yayınlanmıştır. Bu makalelerde diyabet tanı ve tedavisinde rol alan sağlık uzmanları, diyabet eğitimcileri, araştırmacılar, dergi editörleri ve yazarları ile diyabet eğitim yayınları yazarları için diyabetle ilgili saygılı, kapsayıcı, birey odaklı ve yetkilendirici dilin kullanımına yönelik tanımlar yapılmış (Tablo 3) ve nasıl bir dil kullanılması ile ilişkili öneriler sunulmuştur $(2,3)$. Aşağıda kapsamı detaylı olarak açıklanan bu öneriler, Amerikan Psikoloji Derneği (American Psychological Association [APA])'nin, 'Psikolojide Engellilik Sorunları Komitesi' (Committee on Disability Issues in Psychology) tarafindan hazırlanan, engelleyici olmayan/olumlu dili temel alan, yazım kuralları rehberine (27) dayalı olarak geliştirilmiştir.

Yazarlar APA yazım kurallarını dikkate alarak, engelleyici olmayan/olumlu dilin, insanı bir bütün olarak kabul ettiğini bu nedenle de diyabetik çocuk, diyabetik, uyumsuz, kötü kontrolü, motive olmamış şeklinde ki dil kullanımından kaçınılması gerektiğini belirtmişlerdir (2,3). Diyabetli bireylerin bazı kelime ve tanımlamalara gösterdiği tepki ve alternatif dil veya eylem önerileri Tablo 4'de yer almaktadır.

Nötr, yargısız, duruma, eyleme ve fizyolojiye / biyolojiye dayalı dil kullanın: Tıbbi dil, hastalar üzerinde etkili olup, deneyim ve algılamada merkezi bir rol oynamaktadır. Bireyin hastalıkla ilgili dili nasıl duyduğu ve yorumladı̆̆ı, kendi sağlığını ve öz algısını etkilemekte, basit bir tanım ile başlayan ifadeler zamanla pozitif veya negatif çağrışımlara neden olabilmektedir. Yargısal sözler ve mesajların verdiği utanç duygusu, bireyin başkalarından ve bazı durumlardan uzaklaşmasına yol açabilir. Diyabetli yetişkinlerin, sağlık uzmanlarının kullandığı dil nedeniyle yargılanma ve suçlanma ile karşılaştıklarını bildirdikleri belirtilmektedir $(2,3)$. Yargllanma ve suçlanma endişesi ile diyabetlilerin bazen kan glukoz düzeylerini olduğundan farklı kayıt ettiği veya bildirdiği de bilinmektedir.

Tablo 3. Güç ve birey odaklı dil tanımları $(2,3)$

\begin{tabular}{|c|c|}
\hline Önerilen Dil & Tanımlama \\
\hline Güç veren dil & $\begin{array}{l}\text { Bireylerinin ne yapmalarını gerektiğine değil tam tersi; bireylerin neyi bildiklerini ve neler } \\
\text { yapabileceğini vurgular. } \\
\text { Bireylerin kendi sağlıkları ve iyileşmeleri üzerinde daha fazla kontrol sahibi olmalarını sağlayacak, } \\
\text { yetkilendirecek güce odaklanır. Örneğin ‘Ayşe insülin tedavisine uyumlu değil’ yerine ‘Ayşe maliyet } \\
\text { endişesi nedeniyle önerilen insülin dozunun \%50’sini kullanıyor’ }\end{array}$ \\
\hline Birey odaklı dil & $\begin{array}{l}\text { Engeli / hastalığı olan bireylere yönelik farkındalığı, onur duygusunu ve olumlu tutumları gösteren } \\
\text { kelimelerin kullanımı. Engellilikten / hastalıktan ziyade bireye vurgu yapar. Örneğin 'Ayşe diyabetik' } \\
\text { yerine 'Ayşe'nin diyabeti var' }\end{array}$ \\
\hline
\end{tabular}


Tablo 4. Diyabette kullanılan dile diyabetli bireylerin tepkisi ve önerilen dil/eylem önerileri (2,3,6-8)

\begin{tabular}{|c|c|c|}
\hline Kullanılan dil & Diyabetli bireyin tepkisi & Önerilen dil/eylem \\
\hline Diyabetik & $\begin{array}{l}\text {-'Ben bir isim veya sıfat değilim. Ben bir kişiyim’ } \\
\text {-'Ben bir kişiyim; diyabetim beni tanımlamıyor' }\end{array}$ & $\begin{array}{l}\text { Diyabetli birey } \\
\text { Diyabetle yaşayan birey }\end{array}$ \\
\hline Diyabetik ayak & -'Ayağımda mı diyabetik' & Ayak ülseri, ayak infeksiyonu \\
\hline Hasta & $\begin{array}{l}\text {-'Ben sadece hastanedeysem hastayım' } \\
\text {-'Ben hastanede yaşamıyorum' }\end{array}$ & Birey \\
\hline $\begin{array}{l}\text { Uyumsuz, } \\
\text { tedaviye } \\
\text { uymuyor, istekli } \\
\text { değil }\end{array}$ & $\begin{array}{l}\text {-'Bu, diğer insanların söylediklerini kör körüne } \\
\text { yapıp yapmadığım konusunda basit bir etikettir’ } \\
\text {-'Emirleri” takip etmemeyi tercih ediyorsam, } \\
\text { sebeplerim var' } \\
\text {-'HbA1c’min yüksek olduğunu biliyorum ama bu } \\
\text { beni uyumsuz kılmıyor' }\end{array}$ & $\begin{array}{l}\text { “Can, insülin almaya başlamadı çünkü } \\
\text { kilo alımı konusunda endişeli”. } \\
\text { "Karbonhidrat alım düzeyin yüksek” }\end{array}$ \\
\hline Hedef & $\begin{array}{l}\text {-'Hedefler tarafından tanımlanmadım. Ben bir } \\
\text { bireyim’ } \\
\text {-'Bana ne zaman bir sayı, bir hedef verirsen, öz- } \\
\text { bakım iş yükümü arttırıyorsun’ } \\
\text {-'Sen beni rahatsız ediyorsun. Ben sayı değilim' }\end{array}$ & "Kan şekeri düzeyin önerilenden yüksek” \\
\hline $\begin{array}{l}\text { Kontrol, } \\
\text { kontrollü, } \\
\text { kontrolsüz, } \\
\text { iyi kontrollü, } \\
\text { kontrolü yetersiz }\end{array}$ & $\begin{array}{l}\text {-'Diyabetle yaşarken birçok şeyin kontrol etmek } \\
\text { beni güçsüz hissettiriyor' } \\
\text {-'Diyabet gerçekten kontrol edilemiyor, o yüzden } \\
\text { kendimi yargılanıyor hissediyorum’' }\end{array}$ & $\begin{array}{l}\text { "Haftada birkaç kez kan şekeri izlemi/ölçümü } \\
\text { yapabilirsen iyi olur” } \\
\text { "Kullandığin ilaç kan şekeri seviyeni düşürmek için } \\
\text { yeterli değil” } \\
\text { "Birkaç dakika kan şekeri düzeyinle ilişkili } \\
\text { konuşabilir miyiz?” }\end{array}$ \\
\hline Normal, anormal & $\begin{array}{l}\text {-'Normal nedir? Ben bir bireyim. Benim için } \\
\text { normal olan başkası için normal değil' }\end{array}$ & $\begin{array}{l}\text { Bazı insanlar bazı kelimelerden rahatsız olur } \\
\text { bazıları olmaz. Diyabetli bireyin kullandığınız }\end{array}$ \\
\hline Sağlıklı, sağlıksız & $\begin{array}{l}\text {-'Sağlık hakkında konuşurken sadece fiziksel } \\
\text { şeyleri değil refahımı, sıkıntımı ve maddi } \\
\text { durumumu düşünmek zorundasınız’ }\end{array}$ & $\begin{array}{l}\text { kelimelere nasıl tepki verdiğini gözlemleyin, } \\
\text { konuşmaya başladığında onun sözünü kesmeyin. } \\
\text { Kullandığı dili ve kelimeleri dinleyin ve onunla } \\
\text { konuştuğunuzda bu dili ve kelimeleri kullanmaya } \\
\text { çalışın, ancak kullandığınız kelimelerle rahatsız } \\
\text { duyabileceğinin farkında olun. }\end{array}$ \\
\hline
\end{tabular}

Sağlık uzmanları başarılı sonuçları kendilerine, olumsuz sonuçları ise diyabetli bireylere yansıtma eğilimindedirler (6). "Kontrol yeteneği” veya "kontrol yetersizliği” olarak verilen mesajlar ile diyabetli çocuklar 'itaatsiz' çocuklar” ya da diyabetli yetişkinler 'kötü niyetli' olarak nitelendirilebilmektedir. Diyabette 'kontrol' kelimesinin kullanımının klinik araştırmalardan geldiği ve 'Diyabet Kontrolü ve Komplikasyonlar Çalışması' (Diabetes Control Complications Trial [DCCT]) ile pekiştirildiği bildirilmektedir. Kontrol terimi diyabet yönetimi faaliyetlerinde, diyabetli kişiye sorumluluk verirken, aynı zamanda yetki ve bilgi sahibi olan sağlık uzmanının tavsiyelerine kesinlikle uyulmasını da ima etmektedir $(2,3)$.

Toplumda "kontrol altında veya kontrollü” olmanın değeri olduğunu, "kontrolsüz” olmanın ise başarısızlık ile eşdeğer tutulduğunu bildiren araştırmacılar, diyabetli bireylerin kan glukoz seviyelerinin, yiyecek seçimlerinin, vücut ağırlıklarının, fiziksel aktivitelerinin kontrol altında olmasınin ahlaki sonuçları olabileceğini, diyabetli bireyi gerçek dışı bildirimlere yönlendirebileceğini, utanma duygusu oluşturabileceğini bildirmektedirler (2,3,5-9). Bu 
nedenle, diyabetli bireylere, üzerlerinde açık veya net bir yargılama yapan veya sağlıkla ilgili sorunları için onları suçlayan bir dil kullanmadan bakım sağlamak diğer bir ifade ile tarafsız, yargısız, gerçeklere, eylemlere veya fizyolojiye/biyolojiye dayanan bir dil kullanmak daha etkili olabilir (2,3,5,7-9)

Diyabetli bireyler, sıklıkla sağlık çalışanları ve başka bireyler tarafından, yiyecek seçimleri ve yeme alışkanlıkları konusunda eleştirilmiş veya yargılanmış hissederler. Oysaki besinler duygu durumunu düzenleme ve ödüllendirmeyi de kapsayan birçok psikolojik fonksiyona hizmet eder. Sağlıklı beslenme eğitimi hiç kuşkusuz çok önemlidir. Ancak, beslenme tavsiyelerini uygulamaya koymak, beslenme alışkanlıklarını değiştirmek büyük bir çaba harcanmasını gerektirebilir. Besinleri duygusal ya da açlık dışı nedenlerle tüketen bireyler fazladan bir desteğe ihtiyaç duyabilir. Beslenme önerilerini verirken yenilen besinin "neden" ve "ne kadar" yenilmiş olduğuna odaklanmaktan, bireyin kendini yargılanmış, suçlanmış hissediyor olmasından kaçınılması, bunun yerine 'Neden yemek yediğimizin birçok sebebi var, bu konuda konuşmamızı ister misiniz?' gibi bir soru yönelterek duruma, eyleme dayalı bir dil kullanılması önerilmektedir (7).

Sözlü ve yazılı iletişimde diyabetin bir yaşam tarzı hastalığı olduğunun ifade edilmesi diyabetli bireyin doğru beslenmediği ve düzenli egzersiz yapmadığı için kendini suçlamasına neden olabilir. Olumsuz dilin tekrarlanması benlik ve diyabet hakkında olumsuz inançların güçlenmesine yol açabilir $(2,3)$.

Nötr, yargısız, duruma, eyleme ve fizyolojiye/ biyolojiye dayalı dil için İngiliz Diyabet Birliği ve İngiltere Ulusal Sağlık Hizmeti tarafından verilen öneriler aşağıda yer almaktadır $(7,8)$;

- “Kontrol” fikrinden kaçının ve diyabetin genel olarak bireyin yaşamını nasıl etkilediğini tartışın.

- Niyetiniz hakkında daha kesin olun. Örneğin; 'Kan şekeri düzeyleriniz hakkında birkaç dakika konuşabilir miyiz, sizin için işlerin nasıl yürüdüğü hakkında daha iyi bir fikrim olabilir.
- Bireye bakış açısını sorun ve konuşmanızı onun konuşmasına benzer bir dil kullanarak yapın.

- Soru sorurken ses tonunuzun ve sözsüz işaretlerinizin (beden dili) farkında olun ve bunların empatik olmasını hedefleyin.

Damgalamayan dil kullanın: Sağlıkla ilgili damgalama diyabetli bireylerin yaşamlarını olumsuz yönde etkileyen psikolojik bir faktördür. Diyabet yönetiminde "kontrolsüz”, “diyabetik”, "uyumsuz”, “tembel”, “sorumsuz”, "isteksiz” ve "umursamaz” gibi klişeleşmiş, damgalayıcı bir dil kullanılabilmektedir $(2,3)$. Tip 1 ve tip 2 diyabetli birçok bireyin damgalanma yaşadığı (sırasıyla \%76; \%52) saptanmıştır (28). Bu bireylerin bakım talep etme olasılığının daha düşük ve psikolojik sıkıntı hissetme olasılıklarının daha yüksek olduğunun saptandığı bildirilmiştir $(2,3)$. Algılanan damganın, artan psikolojik sıkıntı, depresif belirtiler, azalmış sosyal destek ve düşük yaşam kalitesiyle ilişkili olduğu da belirtilmiştir (28).

Diyabetli bir bireyin 'Diyabetimden nefret ediyorum, yediklerimi kontrol etmem çok zor. Büyük bir çaba gerektiriyor' şeklindeki paylaşımı sağlık uzmanları tarafindan geleneksel olarak "inkar”, "istek eksikliği” veya "uyumsuzluk" olarak kabul edilebilir ve sağlık uzmanlarının, diyabetleri ile "başa çıkmaları" gerektiği ya da "diyabetleriyle uğraşmaya hazır olmadıkları” söylemi ve tepkisi ile karşılaşabilirler. Ayrıca, diyabetli bireyin dile getirdiği bu tür ifadeler, diyabetle yaşamanın zorluklarına karşın klinik olarak kabul edilmiş bir cevap olarak diyabet sıkıntısının varlığını gösterebilir ve bu sıkıntı diyabeti yönetme talebini azaltabilir (7).

Diyabetli bireylerin diyabetle yaşamaktan ve özyönetim yükünden kaynaklanan stresi diğer bir ifade ile diyabet sıkıntısı, suçluluk veya inkâr gibi duyguların yaşandığı duygusal bir durumu ifade eder. Diyabet sıkıntısının, yüksek HbA1c düzeyleri ve azalmış öz yönetim davranışı ile ilişkili olduğu bildirilmiştir (29). Damgalayıcı dil, diyabetlinin öz bakımına zarar verecek psikolojik bir etkiye sahip olabilmektedir. Damgalanmanın yarattığı utancın, 
diyabetli bireyin öz yönetim isteğini azaltabileceği ve diyabet eğitimine katılmasını engelleyebileceği belirtilmiştir $(2,3)$.

Beklenti teorisi diyabette hasta-sağlık çalışanı ilişkisine uyarlanırsa, "uyumsuz”, "yetersiz kontrollü/ kontrolsüz”, "istek uyanmamıs” veya “isteksiz” olarak etiketlenen diyabetli bireyler, bu beklentilerin doğru olduğuna karar verebilir. Örneğin, insülin tedavisine isteksiz olduğu ifade edilen diyabetli birey insülin tedavisini kabul etmeyebilir ve sonuçta diyabet yönetimi ile ilişkili hedeflere ulaşım engellenebilir $(2,3)$. Diyabete bağlı damgalamanın da yüksek A1c düzeyleri ile ilişkili olduğu, kan glukoz düzeylerinde ki artan değişkenliğin suçluluk ve utanç duygusu, yalnız bırakılma algısı yarattığı ve sosyal hayatla ilişkili olumsuz etkileri olduğu bildirilmiştir $(2,3,6,29)$.

Güç ve umut veren, saygılı dil: Güçlendiren (yetki veren) dil, yanlış, eksik veya anormal olan yerine, neyin olduğuna odaklanmaktadır. Bu yaklaşım, insanlara, yeteneklerine, olanaklarına, değerlerine ve umutlarına olan inancı göstermektedir. Hekimlerini, saygısız, samimiyetsiz veya duygusuz olarak algılayan vücut ağırlığı sorunu olan Afrikalı Amerikalıların davranış değişikliği yapma veya ihtiyaç duydukları yardımı arama olasılığının azaldığının saptandığı bildirilmiştir. Oysaki güçlü, saygılı, kapsayıcı ve umut veren bir dil kullanmak iletişimi kolaylaştırabilir $(2,3)$.

Sağllk profesyonellerin "empatik iletişim, hassas sorgulama ve yorumların düşünceli kullanılması” gibi becerilere sahip olmaları istenmektedir $(2,3,5,6)$. Tedaviye uyum, uygunluk, bağlılık kelimelerinin ve bu kelimelerin yer aldığı tedaviye uygun, tedaviye uyumlu, tedaviye bağlı gibi tanımlamaların diyabetli bireyi güçlendirici bir dil olmadığı fark edilmelidir. Sağlık mesleği mensupları, diyabetli bireylerin kendilerine güvenmelerini sağlamalı ve korkularını başarıyla yönetmek için var olan güçlerini kullanmaya teşvik eden bir dil kullanmalıdırlar. Sağlık uzmanları tarafindan dayatılan, zorlamaya maruz biraktıran dil yerine diyabetli bireyler tarafindan belirlenen hedeflere odaklanan dilin kullanılması güçlendirme (yetkilendirme) ile tutarlı kabul edilmektedir $(2,3)$.
Hastalar ve sağlık personeli arasında işbirliğini teşvik eden dil: Sağlık uzmanlarının diyabetli bireyler ile etkileşime girme yolları, diyabetli bireyin tedaviye katılımını ve işbirliğini teşvik edebilir ya da caydırıcı olabilir. Saygılı ve etkili iletişim, sağlık hizmetlerinde güvene dayalı ilişkilerin temelidir. Hasta-sağlık çalışanı ilişkisinin karşılıklı katılım, işbirliği ve diyalog için bir firsat olduğu bildirilmektedir. Hedeflere ulaşmakta zorluk çeken hastalarla iletişim kurmak için suçlayıcı dilden kaçınmalıdır, bu hastanın suçu değildir. Hasta ve sağlık çalışanı arasındaki iletişim, sağlık çalışanlarının hastalarla nasıl bir etkileşimde oldukları ve sağlık çalışanları tarafından önerilen değişiklikleri hastaların ne kadar yaptıkları ile doğrudan ilişkilidir. İşbirlikçi iletişim konusunda eğitim alan uzmanların tedavi verdiği bireylerin öz-yönetim sonuçlarının daha olumlu olduğunun saptandığı bildirilmektedir. Otoriteyi ve güç farkını ima eden 'yaramaz', 'izin verildi/izin verilmedi', 'yapabilir/yapamaz', 'yapmalı/yapmamalı', 'iyi/kötü', 'olmalı/olmamalı’ ve ‘doğru/yanlış’ ifadelerini içeren bir dilin yetişkin diyabetli bireyler tarafından 'sanki çocuklarla konuşuyorlar' şeklinde algılanmasına neden olabildiği belirtilmektedir (2,3). Sağlık çalışanına güvenmek, hasta katılımını artıran ve özyönetimi güçlendiren hasta-sağlık çalışanı ilişkisinin kritik bir unsurudur. Dil, güveni etkileyen güçlü bir unsur olduğundan amaç diyabetli bireylerle sağlık profesyonelleri arasında işbirliğine dayalı bir etkileşim ve tutarlı bir dil kullanmak olmalıdır (5-9).

Birey odaklı dil: Amerikan Geriatri Derneği Uzman Paneli (American Geriatrics Society Expert Panel) bir bireyin yalnızca tıbbi ihtiyaç ve tercihlerini değil tamamını vurgulamak için "hasta merkezli" yerine "birey merkezli” terimini kullanmayı önermektedir. Doktorun veya diğer sağlık bakımı sağlayıcısının birincil karar verici olduğu geleneksel bakım modelinin, sağlık kararlarında bireyin seçimlerini ve özerkliğini destekleyici rolün üstlenildiği birey merkezli bakım ile değiştirebilir olduğu bildirilmiştir (30). Diyabetli bireylerin 'hasta' tanımına algısal yanıtları 'Ben bireyim, hastanede yatmiyorum. Hastaneye yattığım zaman hasta denilebilir' şeklinde 
olduğu bildirilmektedir (5). Bu algı göz önüne alındığında birey odaklı dil yaklaşımının damgalayan, engelleyen dil kullanımını önlediği düşünülebilir.

Birey odaklı dilin, öncelikle engeli olan bireyler için kullanılmaya başlandığı belirtilmektedir. Sağlık hizmeti sağlayıcıları ve araştırmacıların, engelleri vurgulamak yerine, engeli olan bireye vurgu yapmamalarının daha doğru bir yaklaşım olduğu belirtilmektedir (2,3). Birey odaklı dil kullanımda hastalığı ön plana çıkaran 'diyabetik' tanımlaması/ damgası yerine diyabetli bireyi ön plana çıkaran 'diyabetli birey' tanımlamasının yapılmasının önemi vurgulanmaktadir (2,3,5-9).

\section{SONUÇ VE ÖNERİLER}

Dünya genelinde görülme sıklığı giderek artan diyabet yaşam boyu süren, karmaşık ve zorlu bir hastalıktır. Hem diyabetin önlenmesi hem de diyabetin ve komplikasyonlarının tedavisi için verilen mücadelelere, gelişen diyabet teknolojisine, sayıları giderek artan tedavi rehberlerine ve tıbbi tedavi seçeneklerine, güncel diyabet tedavisine yönelik olarak düzenlenen bilimsel toplantılara rağmen diyabetli bireylerin HbA1c düzeylerinde iyileşme sağlanamamaktadır. Kan glukoz düzeylerindeki iyileşmenin sağlanamamasında en önemli engellerden birisi tedaviyi sağlayan sağlık uzmanları ile diyabetli birey arasındaki iletişim sorunlarıdır. Hasta merkezli tedavi yaklaşımının önemli bir parçası olan dil, hasta memnuniyeti ile ilgili olan etkili iletişime katkıda bulunur. İletişimin temel aracı olan dilin sözlü ve/veya yazılı iletişimde iyi kullanılması güven oluşturabilir, önerilen tedaviyi uygulama isteğini arttırabilir, öz yönetimi destekleyebilir ve yaşam kalitesini artırabilir. Diyabet yönetiminde sorumluluğu olan diyetisyenler; tıbbi beslenme tedavisinde beslenme davranışı ile ilişkili önerileri sağlarken ve diyabet eğitimi verirken kullandıkları dile dikkat etmeli, damgalayan, inciten, sıkıntı veren dilden kaçınmalıdır. Diyabetli birey ve yakınları, diyabet ekibinin diğer üyeleri ile hatta tıbbi personel, medya vb. ile olan iletişimlerimizde kullandığımız yazılı ve sözlü ifadelerimizde diyabet dili ile ilişkili önerileri dikkate almalı ve sağlık ekibinin diğer üyelerinde de diyabet dili farkındalığını sağlamaya çalışmalıyız.

Çıkar çatışması - Conflict of interest: Yazarlar çıkar çatışması olmadığını beyan ederler. - The authors declare that they have no conflict of interest.

\section{KAYNAKLAR}

1. American Diabetes Association. Introduction: Standards of medical care in diabetes 2019. Diabetes Care. 2019;42 (Suppl. 1):S1-S2.

2. Dickinson JK, Guzman SJ, Maryniuk MD, O’Brian CA, Kadohiro JK, Jackson RA, et al. The use of language in diabetes care and education, diabetes care. Diabetes Care. 2017;40:1790-9.

3. Dickinson JK, Guzman SJ, Maryniuk MD, O’Brian CA, Kadohiro JK, Jackson RA, et al. The Use of Language in Diabetes Care and Education. Diabetes Educ. 2017;43(6):551-64.

4. Türk Dil Kurumu. Dil. Erişim: https://sozluk.gov.tr/ Erişim tarihi: 29 Kasım 2019.

5. Lloyd CE, Wilson A, Holt RIG, Whicher C, Kar P, on behalf of the Language Matters Group. Language matters: a UK perspective. Diabet Med. 2018;35:1635-41.

6. Dunning $\mathrm{T}$, Speight $\mathrm{J}$, Bennett $\mathrm{C}$. Language, the "Diabetes restricted code/dialect," and What it means for people with diabetes and clinicians. Diabetes Educ. 2017;43(1):18-26.

7. Cooper A, Kanumilli N, Hill J, Holt RIG, Howarth D, Lloyd $\mathrm{CE}$, et al. Diabetes UK Position Statements Language matters. Addressing the use of language in the care of people with diabetes: position statement of the English Advisory Group. Diabet Med. 2018;35:1630-4.

8. NHS, England. Language Matters. Language in Diabetes. NHS England Gateway Number: 07922, June 2018.

9. Speight J, Conn J, Dunning T, Skinner TC. Diabetes Australia. Diabetes Australia position statement. A new language for diabetes: improving communications with and about people with diabetes. Diabetes Res Clin Pract. 2012;97:425-31.

10. Rathert C, Wyrwich MD, Boren SA. Patient centered care and outcomes: a systematic review of the literature. Med Care Res Rev. 2013;70:351-79.

11. American Diabetes Association. Improving care and promoting health in populations: Standards of medical care in diabetes-2019. Diabetes Care. 2019; 42(Suppl. 1):S7-S12. 
12. Naughton CA. Patient-Centered Communication. Pharmacy (Basel). 2018;6(1):18.

13. Williams JS, Walker RJ, Smalls BL, Hill R, BA, Egede LE. Patient-centered care, glycemic control, diabetes selfcare, and quality of life in adults with type 2 diabetes. Diabetes Technol Ther. 2016;18(10):6446-49.

14. American Diabetes Association. Comprehensive medical evaluation and assessment of comorbidities; Standards of medical care in diabetes-2019. Diabetes Care. 2019;42(Suppl. 1):S34-S4.

15. Paiva D, Abreu L, Azevedo A, Silva S. Patient-centered communication in type 2 diabetes: The facilitating and constraining factors in clinical encounters. Health Serv Res. 2019;54(3):623-35.

16. Iverson C, Christiansen S, Flanigan A, Fontanarosa PB, Glass RM, Gregoline B, et al. AMA Manual of Style. 10th ed. New York, Oxford University Press, 2007, p.416-417.

17. Rimal RN, Lapinsk MK. Why health communication is important in public health. Bulletin of the World Health Organization. 2009;87:247-247.

18. United States Department of Health \& Human Services. Healthy people 2010. Available at: https://www.cdc. gov/nchs/data/hpdata2010/hp2010_final_review.pdf Accessed November 29, 2019.

19. Parrott R. Emphasizing “communication" in health communication. J Commun. 2004;54:751-87.

20. Sohal T, Sohal P, King-Shier KM, Khan NA. Barriers and facilitators for Type-2 diabetes. Management in South Asians: A systematic review. PLoS One 2015;10(9):e0136202.

21. Nicolucci A, Kovacs Burns K, Holt RI, Comaschi M, Hermanns $\mathrm{N}$, Ishii $\mathrm{H}$, et al. DAWN2 Study Group. Diabetes attitudes, wishes and needs second study (DAWN2 ${ }^{\mathrm{TM}}$ ): cross- national benchmarking of diabetesrelated psychosocial outcomes for people with diabetes.
Diabet Med. 2013;30(7):767-77.

22. Reader TW, Gillespie A, Roberts J. Patient complaints in healthcare systems: a systematic review and coding taxonomy. BMJ Qual Saf. 2014;23(8):678-89.

23. Stossel LM, Segar N, Gliatto P, Fallar R, Karani R. Readability of patient education materials available at the point of care. J Gen Intern Med. 2012;27(9):1165-70.

24. Centers for Medicare and Medicaid Services (CMS). Toolkit for Making Written Material Clear and Effective. Available at: https://www.cms.gov/Outreachand Education/Outreach/WrittenMaterials Toolkit/ index?redirect=/ WrittenMaterialsToolkit. Accessed: November 29, 2019.

25. International Diabetes Federation. International Diabetes Federation Language Philosophy: Technical Document. International Diabetes Federation, Brussels, Belgium, 2014.

26. Palad CJ, Stanford FC. Use of people-first language with regard to obesity. Am J Clin Nutr. 2018;108(1):201-03.

27. American Psychological Association. Guidelines for nonhandicapping language in APA journals. Available at: httsp://www.apastyle.org/manual/related/ nonhandicapping-language Accessed November 29, 2019.

28. Liu NF, Brown AS, Folias AE, Younge MF, Guzman SJ, Close KL, et al. Stigma in people with type 1 or type 2 diabetes. Clin Diabetes. 2017;35(1):27-34.

29. Kreider KE. Diabetes distress or major depressive disorder? A practical approach to diagnosing and treating psychological comorbidities of diabetes. Diabetes Ther. 2017;8(1):1-7.

30. American Geriatrics Society Expert Panel on PersonCentered Care. Person-centered care: a definition and essential elements. J Am Geriatr Soc. 2016;64:15-8. 